\title{
PENERAPAN ALAT PERAGA PAPAN AJAIB UNTUK MATERI OPERASI HITUNG PECAHAN
}

\author{
Arfatin Nurrahmah ${ }^{1}$, Nurul Hikmah ${ }^{2}$, Rita Kusumawardani $^{3}$ \\ ${ }^{1,2,3}$ Universitas Indraprasta PGRI \\ 1e-mail: arfatinnurrahmah@gmail.com
}

\begin{abstract}
Abstrak
Kegiatan pengabdian masyarakat dilaksanakan di SMP Al-Nur Cibinong. Pengabdian masyarakat dilaksanakan dengan tujuan membantu siswa yang mengalami kesulitan dalam memahami dan mengerjakan soal-soal materi Operasi Hitung Pecahan. Dalam pembelajaran Matematika, suatu konsep mudah dipahami dan diingat oleh siswa jika konsep tersebut disajikan melalui prosedur dan langkahlangkah yang didesain secara tepat, jelas, dan menarik. Salah satu cara adalah dengan menggunakan media belajar, yaitu alat peraga. Alat peraga diharapkan dapat membantu memahami konsep Matematika dengan lebih mudah dan menyenangkan sehingga pengalaman belajar akan tertanam dengan baik. Guru dapat merangsang siswa untuk terlibat secara aktif dalam pembelajaran Matematika dengan menggunakan alat peraga Papan Ajaib untuk materi Operasi Hitung Pecahan. Alat peraga dapat digunakan dengan mudah hanya dengan meletakkan angka-angka di sebuah papan. Di dalam papan sudah terdapat alur untuk menghitungnya. Dengan begitu diharapkan penggunaan alat peraga dapat membantu mengatasi kesulitan belajar Matematika siswa terutama dalam materi Operasi Hitung Pecahan.
\end{abstract}

Kata Kunci: penerapan, alat peraga, Papan Ajaib.

\begin{abstract}
This community service activity was conducted at SMP Al-Nur Cibinong. This community service is implemented with the aim of assisting students who have difficulty in understanding and working on material matter of integer and fractional operations. In learning mathematics, a concept is easily understood and remembered by learners if the concept is presented through procedures and measures that are designed precisely, clearly, and appealing. One way is to use learning media, ie props. The visual aids are expected to help understand mathematical concepts more easily and fun so the learning experience will be well embedded. Teachers can stimulate learners to be actively involved in learning mathematics using Magic Board props for Fractional Counting Materials. This tool can be used easily just put the numbers on a board. Inside the board there is a groove to calculate it. With so expected the use of props can help overcome learning difficulties learners math especially in material fractions counting operations.
\end{abstract}

Keywords: implementation, display tool, Magic Board.

\section{PENDAHULUAN}

Pendidikan memiliki peran dan pengaruh positif terhadap perkembangan manusia dengan berbagai aspek kepribadiaannya di segala bidang kehidupan. Pengaruh dari pendidikan dapat dirasakan dan dilihat secara langsung, baik dalam kehidupan individu, masyarakat maupun dan suatu bangsa. Pendidikan berurusan langsung dengan pembentukan manusia, karena seorang individu akan berkulitas 
jika pendidikan yang diberikan kepadanya juga berkualitas. Guru sebagai seorang pendidik, mempunyai peran penting dalam upaya meningkatkan kualitas pendidikan Indonesia. Hal tersebut perlu diwujudkan agar diperoleh kualitas sumber daya manusia Indonesia yang dapat menunjang pembangunan nasional. Seorang guru langsung membina para siswa di sekolah melalui proses belajar.

Seorang guru harus mempersiapkan berbagai cara dan strategi agar materi yang diajarkan kepada siswa dapat diterima serta dapat dipahami dengan mudah. Kualitas kegiatan pembelajaran yang dilakukan sangat bergantung pada perencanaan dan pelaksanaan proses pembelajaran yang dilakukan guru. Tugas guru bukan semata-mata mengajar (teacher centered), tetapi lebih kepada membelajarkan siswa (students centered). Keberhasilan proses pembelajaran tidak terlepas dari keterlibatan siswa secara efektif di dalam proses pembelajaran. Pada dasarnya, siswa lebih baik jika belajar melalui benda maupun objek konkret. Untuk memahami konsep abstrak, siswa memerlukan benda-benda konkret sebagai perantara atau visualisasinya. Bahkan orang dewasapun yang pada umumnya sudah dapat memahami konsep abstrak, pada keadaan tertentu sering memerlukan visualisasi.

Keberhasilan pembelajaran Matematika dapat diukur dari keberhasilan siswa mengikuti pelajaran dan dapat dilihat dari tingkat pemahaman, penguasaan materi serta hasil belajar siswa. Semakin tinggi pemahaman dan penguasaan materi, semakin tinggi pula tingkat keberhasilan pembelajaran, yaitu berupa hasil belajar yang semakin baik. Namun dalam kenyataannya, siswa masih mengalami kesulitan dalam mengikuti pembelajaran Matematika, karena kurang memahami konsep pelajaran Matematika secara utuh. Siswa diharapkan benar-benar aktif selama proses pembelajaran, sehingga akan berdampak pada hasil belajar yang didapat. Suatu konsep mudah dipahami dan diingat oleh siswa bila konsep tersebut disajikan melalui prosedur dan langkah-langkah kegiatan pembelajaran yang didesain secara tepat, jelas, dan menarik sesuai dengan materi pembelajaran. Salah satu cara agar siswa dapat mengatasi kesulitan belajar Matematika adalah dengan cara menggunakan media pembelajaran yaitu alat peraga. Alat peraga diharapkan dapat membantu memahami konsep Matematika dengan lebih mudah 
dan menyenangkan sehingga pengalaman belajar akan tertanam dengan baik. Dengan menggunakan alat peraga, diharapkan siswa akan merasakan variasi pembelajaran di kelas, sehingga pembelajaran tidak membosankan dan materi akan lebih mudah dipahami dan bertahan lebih lama.

Berdasarkan hasil wawancara dengan guru mata pelajaran Matematika serta beberapa siswa kelas tujuh SMP Al-Nur Cibinong, diperoleh informasi bahwa pembelajaran Matematika hanya berpusat pada guru sebagai sumber belajar. Guru kurang berimprovisasi dalam proses pembelajaran, baik dari segi penyampaian maupun penyajian materi. Dalam menyajikan materi Matematika, guru jarang menggunakan media pembelajaran, seperti alat peraga. Padahal alat peraga juga dibutuhkan untuk memudahkan guru dalam penyajian materi, agar siswa lebih memahami materi dengan baik. Siswa belajar Matematika lebih banyak melalui penjelasan secara langsung oleh guru tanpa adanya keterlibatan langsung dalam proses pembelajaran.

Guru lebih sering menyampaikan materi dengan metode ceramah, sehingga siswa kurang aktif selama proses pembelajaran karena guru lebih mendominasi. Proses pembelajaran berupa ceramah yang berpusat pada guru (teacher centered) menyebabkan kemampuan berpikir siswa kurang berkembang. Transfer ilmu hanya berlangsung satu arah, siswa hanya duduk manis mendengarkan penjelasan guru. Akibatnya siswa cenderung menghapal konsep, sehingga pembelajaran Matematika berlangsung membosankan karena tidak ada aktivitas yang menyenangkan. Siswa tidak termotivasi dalam belajar Matematika dan tidak adanya minat untuk mempelajari Matematika karena masih beranggapan bahwa Matematika merupakan pelajaran yang sulit untuk dipahami. Kurangnya pemahaman siswa dalam materi Operasi Hitung Pecahan terlihat dari nilai Matematika yang diperoleh siswa masih berada di bawah KKM (Kriteria Ketuntasan Minimal).

\section{METODE}

Kegiatan pengabdian masyarakat dimulai dengan mengurus perizinan dan peninjauan daerah mitra yang dilakukan selama dua bulan hingga pelaksanaan. 
Tempat kegiatan pengabdian masyarakat di SMP Al-Nur yang terletak di Jalan Al-Nur Kelurahan Paburuan, Kecamatan Cibinong, Kabupaten Bogor. Target pelaksanaan kegiatan adalah seluruh perangkat sekolah SMP Al-Nur Cibinong, yang terdiri dari kepala sekolah, guru Matematika, serta siswa kelas VII.

Metode yang digunakan dalam kegiatan pengabdian masyarakat dilakukan dengan cara mendatangi lokasi kegiatan SMP Al-Nur,Cibinong. Metode pelaksanaan kegiatan adalah sebagai berikut: (1) Observasi. Observasi dilakukan untuk mendapatkan informasi mengenai pembelajaran Matematika yang biasa dilakukan di SMP Al-Nur. Diperoleh data berupa keadaan sekolah, suasana kelas pada saat pembelajaran, metode pembelajaran yang digunakan guru, sikap siswa terhadap pembelajaran, serta permasalahan-permasalahan mengenai pembelajaran Matematika di sekolah; (2) Diskusi. Diskusi dilakukan untuk membahas solusi dari permasalahan-permasalahan yang muncul dalam pembelajaran Matematika. Diskusi terjadi antara tim pengabdian dengan mitra kegiatan, yaitu kepala sekolah dan guru Matematika SMP AL-Nur. Dari diskusi diperoleh solusi untuk permasalahan pembelajaran Matematika, yaitu penggunaan alat peraga dalam pembelajaran Matematika; (3) Dokumentasi. Dokumentasi dalam kegiatan dilakukan untuk memperoleh data-data fisik yang berhubungan dengan pembelajaran Matematika, seperti nilai ulangan siswa dan rencana pelaksanaan pembelajaran; (4) Demonstrasi. Demonstrasi dilakukan untuk memberikan contoh penggunaan permainan tradisional kepada guru. Demonstrasi juga dilakukan dalam perancangan pembelajaran dengan penggunaan alat peraga; (6) Praktik. Praktik merupakan inti dari kegiatan. Praktik dilaksanakan pada saat pembelajaran, yaitu guru memperkenalkan alat peraga Papan Ajaib untuk Operasi Hitung Pecahan kepada siswa.

\section{HASIL DAN PEMBAHASAN}

Pelaksanaan kegiatan dilakukan dalam tiga tahap, yaitu tahap persiapan, pelaksanaan, dan evaluasi. Tahap pertama adalah tahap persiapan. Pada tahap persiapan, tim melakukan survei pendahuluan dan wawancara awal terhadap guru serta beberapa siswa, untuk mengetahui target kegiatan, kondisi peserta yang akan 
diberikan perlakuan dan menyusun rancangan kegiatan yang akan dilakukan. Tahap persiapan selanjutnya, tim menyiapkan bahan-bahan yang akan dijadikan alat peraga sebagai materi pengabdian masyarakat. Alat dan bahan yang digunakan adalah: papan multiplek $6 \mathrm{~mm}$, gergaji kecil, paku kecil, aquaproof, karton, hanger frame, cutter, roll cat, gunting, kuas, biang warna, cat tembok, baut, ring, mur, dan amplas.

Cara pembuatan alat peraga adalah: (1) Buat sketsa terlebih dahulu dari alat peraga yang akan dibuat; (2) Potong triplek dengan ukuran $85 \mathrm{~cm}$ x $60 \mathrm{~cm}$ yang akan digunakan sebagai papan utamanya (background); (3) Potong triplek yang lain berbentuk persegi panjang dengan ukuran $7,5 \mathrm{~cm}$ x $5 \mathrm{~cm}$ yang digunakan untuk angka sebanyak 40 buah serta satu lingkaran; (4) Lakukan pengecetan untuk background dengan warna pertama (warna sesuai dengan kesukaan). Untuk triplek yang digunakan untuk angka, dibagi menjadi 4 warna (warna bebas). Warna kedua 4 buah, warna ketiga 8 buah, warna keempat 12 buah, dan warna kelima 20 buah; (5) Untuk lingkaran dibagi menjadi 6 bagian kemudian diberi warna bebas yang berbeda untuk setiap bagian secara selang seling lalu tuliskan simbol postif dan negatif secara selang seling pula; (6) Papan yang sudah dicat dilubangi sesuai dengan sketsa yang sudah ada, kemudian pasangkan baut; (7) Tulis angka 0 - 9 pada papan angka masing-masing rangkap 4 (empat); (8) Buat lambang operasi hitung dari papan triplek (tambah, kurang, kali, bagi); (9) Pada papan besar yang digunakan sebagai background ditambahkan beberapa warna memperindah serta beberapa garis hitam panjang untuk pemisah antara pembilang dan penyebut pada pecahan, serta alur atau cara menghitungnya; (10) Pasang baut di papan background, lalu pasangkan semua papan angka, lingkaran, dan yang lainnya sesuai dengan sketsa yang sudah dibuat sebelumnya; (11) Buat garis tepi pada papan dan pada bagian belakang papan diberi balok di sekelilingnya, serta pasang tali untuk menggantungkan alat tersebut. Alat peraga siap digunakan. 

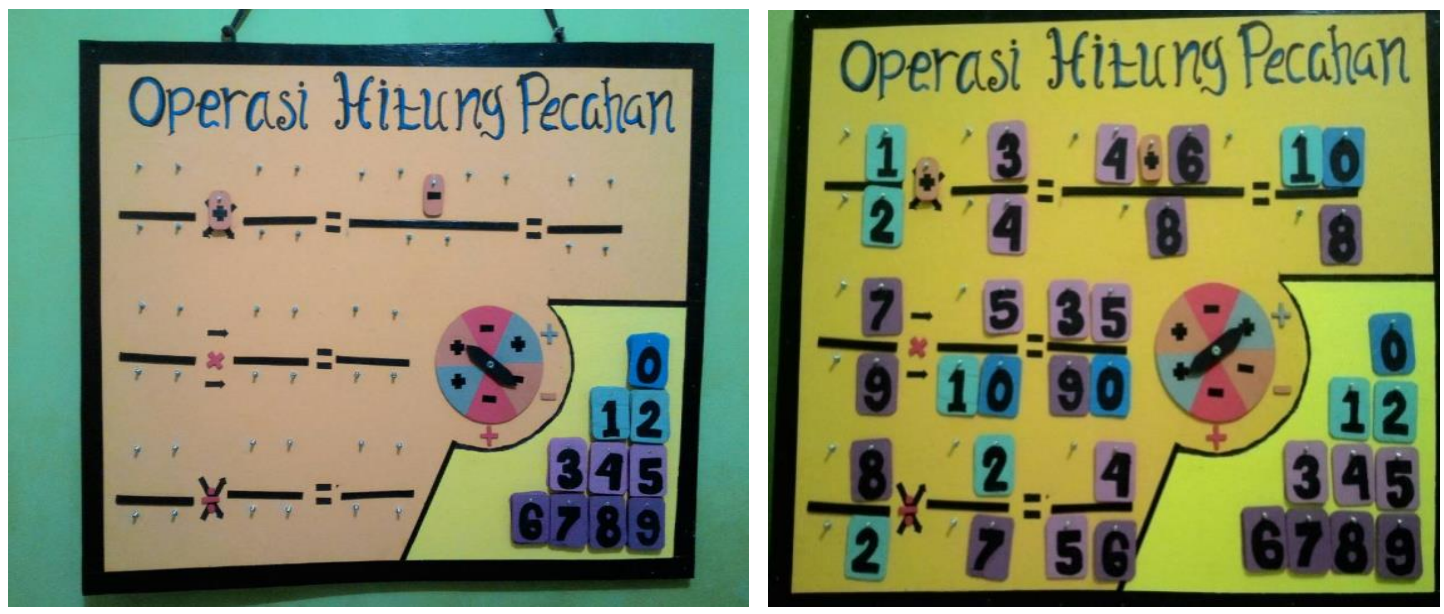

\section{Gambar 1 Alat Peraga Papan Ajaib}

Tahap kedua yaitu tahap pelaksanaan. Kegiatan dilakukan tim dengan memberikan informasi kepada guru Matematika mengenai alternatif penyampaian dan penyajian materi yang menarik dan menyenangkan, salah satunya adalah dengan menggunakan alat peraga.

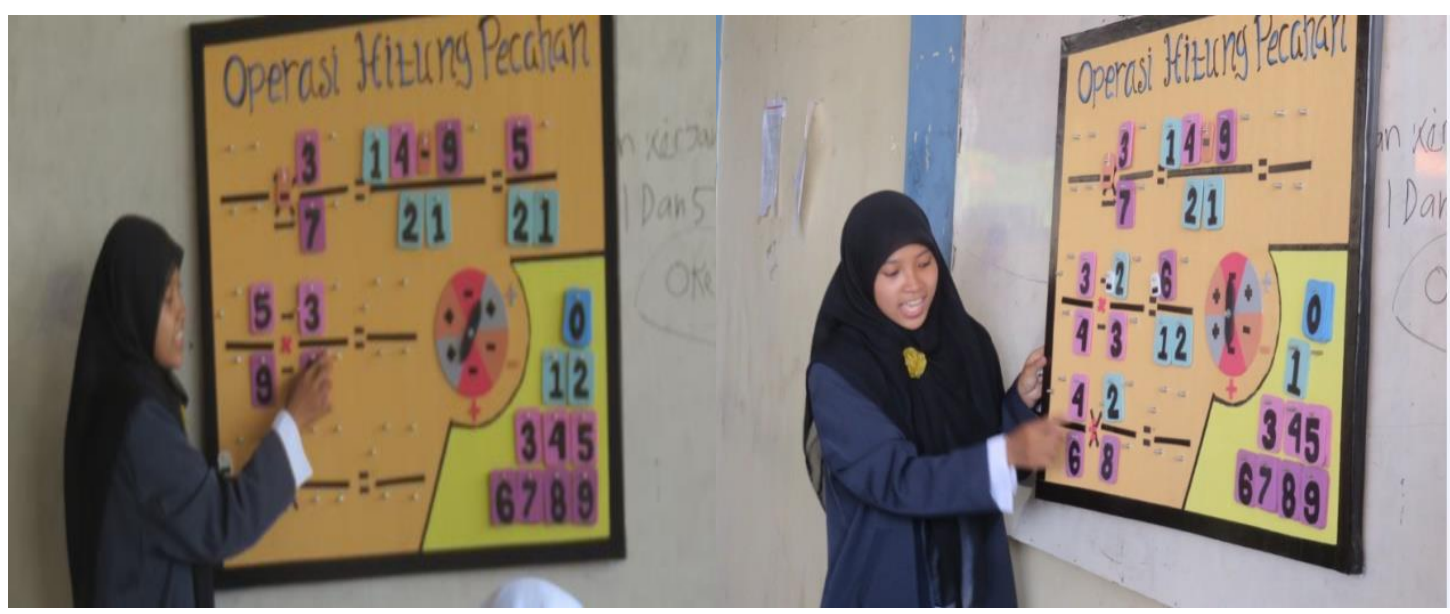

Gambar 2 Tim Menjelaskan Cara Menggunakan Alat Peraga

Kegiatan selanjutnya adalah menjelaskan tentang alur dan cara menggunakan alat peraga Papan Ajaib dan memberikan contoh soal tentang materi Operasi Hitung Pecahan menggunakan alat peraga Papan Ajaib. Tahap pelaksanaan terakhir yaitu memberikan kesempatan kepada guru untuk mensimulasikan alat peraga kepada siswa di dalam kelas. Alat peraga dapat digunakan dengan mudah hanya dengan meletakkan angka-angka di papan 
(pembilang dan penyebut), kemudian ikuti alur untuk menyelesaikan soal yang diberikan. Operasi yang dapat dilakukan adalah penjumlahan, pengurangan, perkalian, dan pembagian.

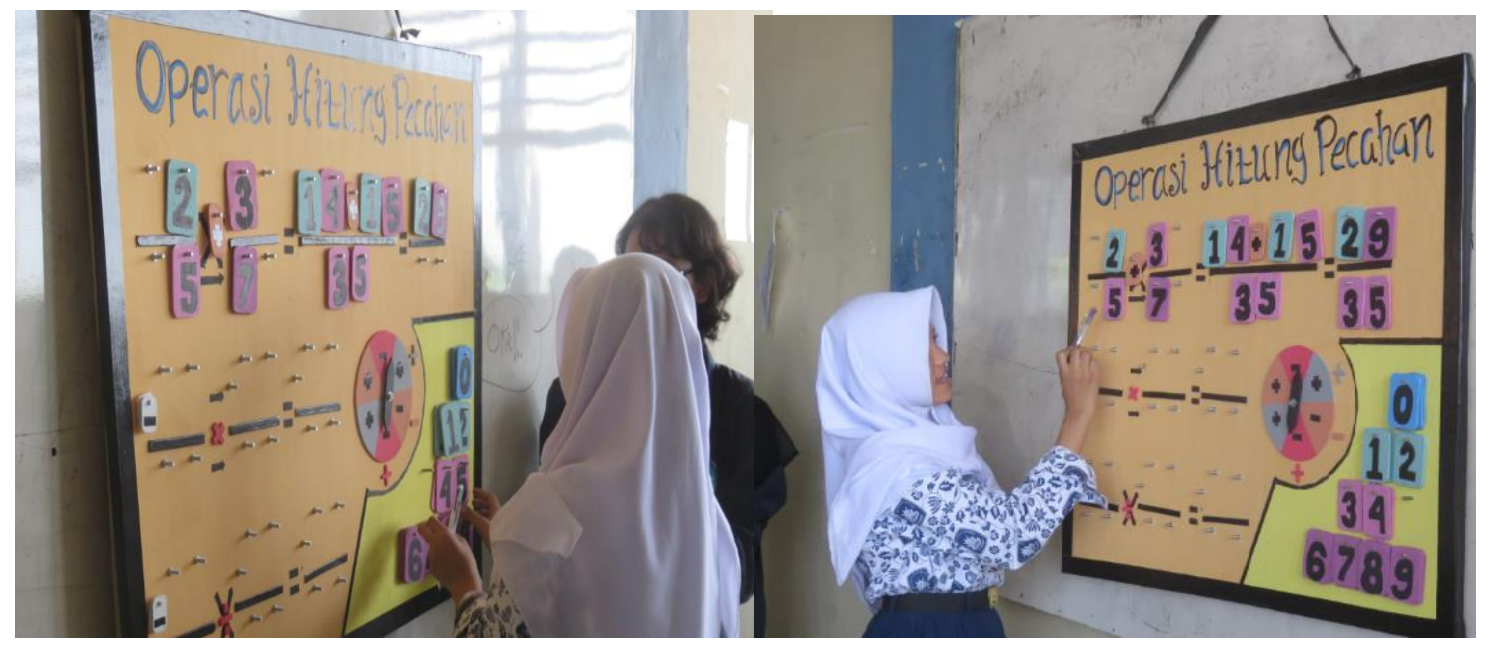

Gambar 3 Siswa Mengerjakan Soal

Tahap yang terakhir adalah tahap evaluasi. Evaluasi kegiatan dilakukan terhadap proses kegiatan. Evaluasi proses berkaitan dengan kehadiran peserta, semangat, dan antusias peserta mengikuti kegiatan dan kerja sama yang terjalin selama proses pelaksanaan, dan tingkat pemahaman siswa setelah menerima materi dari guru dengan menggunakan alat peraga. Evaluasi proses dilakukan selama kegiatan berlangsung. Evaluasi dilakukan sebagai bahan pertimbangan apabila ingin melakukan kegiatan pengabdian masyarakat selanjutnya.

\section{HASIL DAN PEMBAHASAN}

SMP Al-Nur merupakan lembaga pendidikan dasar formal. Para siswa SMP Al-Nur memiliki karakteristik yang beragam. Hasil observasi dan wawancara terhadap guru diperoleh bahwa pembelajaran Matematika masih menerapkan metode ceramah. Hal tersebut dikarenakan pembelajaran dengan metode ceramah lebih mudah dan tidak perlu mengeluarkan waktu serta biaya banyak. Penggunaan metode ceramah membuat guru lebih banyak menjelaskan materi sehingga siswa kurang terlibat aktif dalam proses pembelajaran. Suasana pembelajaran yang monoton dan "itu-itu saja" mengakibatkan siswa kurang menyukai pelajaran 
Matematika sehingga terkadang hasil belajar yang didapatkan siswa masih juga belum memenuhi kriteria yang ditetapkan sekolah. Berdasarkan hasil wawancara dengan guru, dikemukakan juga bahwa siswa masih merasa kesulitan dalam memahami materi pecahan. Padahal materi pecahan sudah dipelajari di jenjang sebelumnya yaitu sekolah dasar, namun ternyata hasil belajar yang didapatkan masih belum memenuhi target yang diinginkan. Berdasarkan hasil pengamatan tim, diperlukan adanya variasi pembelajaran agar siswa tidak cepat bosan, misalnya dengan menggunakan media belajar. Sehingga langkah pertama yang tim lakukan adalah berbagi informasi kepada guru-guru Matematika mengenai inovasi pembelajaran, khususnya mengenai penggunaan media belajar (alat peraga).

Menurut Anitah, dkk (2008: 63) media merupakan alat bantu saluran komunikasi. Media adalah alat bantu yang dapat dijadikan sebagai penyalur pesan guna mencapat tujuan pengajaran. Salah satu media pembelajaran yang dapat digunakan yaitu alat peraga. Alat peraga merupakan media yang dapat digunakan mengongkritkan pemahaman siswa yang masih abstrak. Penggunaan alat peraga bertujuan agar pembelajaran menjadi aktif dan kreatif, serta membantu siswa dalam memahami materi. Oleh karenanya, guru harus bisa memilih alat peraga agar alat peraga yang digunakan tidak menambah kebingungan pada siswa dalam memahami materi.

Ada beberapa hal yang perlu diperhatikan guru dalam menggunakan alat peraga untuk memperbaiki kualitas pengajaran. Pertama, guru perlu memiliki pemahaman media pengajaran antara lain jenis dan manfaat media sebagai alat bantu mengajar dan tindak lanjut penggunaan media salam proses belajar siswa. Kedua, guru harus terampil dalam membuat media pengajaran sederhana untuk keperluan pengajaran, terutama media dua dimensi atau media grafis, dan beberapa media tiga dimensi. Ketiga, pengetahuan dan keterampilan dalam menilai keefektifan penggunaan media dalam proses pengajaran. Menilai keaktifan media pengajaran berhubungan dengan hasil belajar yang didapat siswa. Apabila penggunaan media pengajaran tidak mempengaruhi proses dan kualitas 
pembelajaran, sebaiknya guru tidak memaksakan penggunaannya dan perlu mencari alternatif lain.

Nilai media dalam pendidikan dan pembelajaran dilatari beberapa alasan, antara lain: (1) Media bersifat kongkrit sehingga anak dapat melihat dengan jelas sesuatu yang sedang dibicarakan dalam media selain penjelasan dengan kata-kata; dan (2) Media dapat dibuat dengan harga yang terjangkau dan penggunaannya dapat dilakukan terus menerus. Dalam membuat alat peraga yang baik dan menarik, pada lazimnya terdapat sejumlah kriteria yang dapat digunakan sebagai parameter, antara lain: keaslian alat peraga, yaitu menunjukkan situasi yang sebenarnya; kesederhanaan, alat peraga yang sederhana dalam bentuk, menimbulkan kesan tertentu, mempunyai nilai estetis secara murni dan mengandung nilai praktis; cara pembuatan, alat peraga hendaknya menunjukkan kesederhanaan cara pembuatannya.

Materi pecahan merupakan salah satu pengetahuan awal dalam Matematika. Materi pecahan dipelajari di tingkat sekolah dasar, yaitu mengenalkan konsep pecahan (pembilang dan penyebut) dan operasi pecahan (penjumlahan, pengurangan, perkalian, dan pembagian). Konsep pecahan merupakan salah satu konsep yang dianggap sulit dipahami oleh sebagian siswa SMP, terutama di SMP Al-Nur, Cibinong. Dari wawancara dengan siswa didapatkan kesimpulan bahwa siswa masih kebingungan dalam melakukan operasi pecahan karena sulit membedakan cara penyelesaiannya. Penjelasan dari gurupun kadang sulit dipahami siswa karena tidak ada contoh kongkrit.

Rumini, dkk. (Irham dan Wiyani, 2013: 54) mengemukakan bahwa kesulitan belajar merupakan kondisi saat siswa mengalami hambatan-hambatan tertentu untuk mengikuti proses pembelajaran dan mencapai hasil belajar secara optimal. Dari hasil pengamatan tim, dalam menyampaikan materi operasi pecahan, guru memerlukan alat peraga agar siswa mampu menangkap arti sebenarnya konsep tersebut. Penyampaian informasi yang hanya melalui bahasa verbal memungkinkan terjadinya verbalisme, artinya siswa hanya mengetahui tentang kata tanpa memahami dan mengerti makna yang terkandung dalam kata tersebut. Alat peraga yang dibuat oleh tim yaitu alat peraga "Pecahan Papan 
Ajaib“. Tim menjelaskan kepada guru cara penggunaan alat peraga ini. Alat ini dapat digunakan dengan mudah hanya dengan meletakkan angka-angka di sebuah papan, dan mengikuti alur untuk menyelesaikan soal yang diberikan. Kemudian guru menjelaskan materi operasi pecahan di kelas dengan menggunakan alat peraga yang diberikan.

Hasil yang diperoleh dari kegiatan pengabdian adalah timbulnya rasa antusias dari guru untuk mengembangkan kreativitas dalam penyajian materi. Guru menyambut positif kegiatan pengabdian dikarenakan membantu guru untuk memperbaiki dan menambah alternatif pembelajaran yang dapat dilakukan di kelas. Dengan adanya alat peraga, memudahkan guru dalam penyampaian informasi dan memudahkan siswa dalam memperjelas konsep operasi pecahan. Interaksi antara guru dan siswa terjalin dengan baik, serta suasana di kelas tidak hanya didominasi oleh guru. Alat peraga dalam proses pembelajaran mempunyai nilai-nilai diantaranya, yaitu: (1) Peragaan dapat meletakkan dasar-dasar yang nyata untuk berpikir; (2) Peragaan dapat memperbesar minat dan perhatian siswa untuk belajar; (3) Peragaan dapat meletakkan dasar untuk perkembangan belajar sehingga hasil belajar dapat maksimal; (4) Peragaan memberikan pengalaman nyata dan dapat menumbuhkan kegiatan berusaha sendiri pada setiap siswa; (5) Peragaan menumbuhkan pemikiran yang teratur dan berkesinambungan; (6) Peragaan membantu timbulnya pemikiran dan berkembangnya kemampuan bahasa; dan (7) Peragaan memberikan pengalaman yang tidak mudah diperoleh dengan cara lain serta membantu berkembangnya efisiensi dan pengalaman belajar yang lebih sempurna (Sudjana, 2005: 100).

\section{SIMPULAN}

Kegiatan pengabdian masyarakat telah memberi kontribusi positif sebagai upaya untuk menciptakan hasil belajar yang optimal dan menciptkan pembelajaran Matematika yang bermakna. Kegiatan pengabdian telah berjalan dengan baik dan dapat disimpulkan sebagai berikut: (1) Guru antusias dalam pelaksanaan kegiatan dan termotivasi untuk menciptakan pembelajaran yang menyenangkan dengan menggunakan media pembelajaran; (2) Munculnya minat 
dan motivasi siswa dalam belajar Matematika setelah pelaksanaan kegiatan serta mulai terlatih untuk terlibat aktif dalam proses pembelajaran; (3) Guru dapat menggunakan alat peraga dan dapat berinovasi menciptakan alat peraga lain yang dapat digunakan untuk menyampaikan materi; dan (4) Alat peraga yang diberikan dapat digunakan seterusnya sesuai dengan materi yang disampaikan.

Berdasarkan simpulan, maka saran dan rekomendasi yang diberikan sebagai berikut: (1) Guru harus selalu meningkatkan keaktifan dan motivasi belajar matematika siswa agar hasil belajar yang didapatkan sesuai dengan kompetensi yang ingin dicapai; (2) Guru hendaknya menerapakan model pembelajaran yang inovatif dan menggunakan media pembelajaran yang mudah dibuat agar pembelajaran lebih menyenangkan bagi siswa; (3) Pihak terkait seperti Dinas Pendidikan perlu memberikan perhatian khusus dalam upaya meningkatkan kualitas pembelajaran matematika; dan (4) Kegiatan pelatihan yang serupa perlu dilaksanakan secara berkesinambungan, intensif dengan melibatkan lebih banyak peserta dan pihakt terkait seperti Dinas Pendidikan, LPMP, Perguruan Tinggi secara kolaboratif.

\section{DAFTAR PUSTAKA}

Abdurrahman, M. 2003. Pendidikan bagi Anak Berkesulitan Belajar. Jakarta: Rineka Cipta.

Anita, S. dkk. 2008. Strategi Pembelajaran di SD. Jakarta: Universitas Terbuka.

Djamarah, S. B. 2002. Psikologi Belajar. Jakarta: Rineka Cipta.

Irham, M. \& Wiyani, A. N. 2013. Psikologi Pendidikan. Yogyakarta: Ar-Ruzz Media.

Sudjana, N. 2005. Dasar-dasar Proses Belajar Mengajar. Bandung: Sinar Baru Algensindo.

Wina, S. 2007. Strategi Pembelajaran Berorientasi Standar Proses Pendidikan. Jakarta : Kencana Prenada Media Group. 